\title{
Zakat as an Obligatory System and its Implications for Social Psychology of Society (Social Tafsīr of Sürah Al-Tawbah: 103)
}

\author{
Abdul Wahid Al-Faizin \\ Airlangga University \\ Taqiyah Dinda Insani \\ Airlangga University \\ Tika Widiastuti \\ Airlangga University
}

\begin{abstract}
In the current literature, the study of the collective benefits of Zakat is more emphasized on the material economic aspects by using modern economic tools. Meanwhile, Zakat has a significant social role in the community. Therefore, Allah mentions in Qur'an the command of Zakat and prayer together as much as 22 times. It shows that the role of Zakat socially in human relationships with each other is comparable to the relationship with God. This paper will try to explore and analyze the social role (Social Psychology) of Zakat as an obligatory system from Sürah alTawbah: 103. The method used in this paper is a qualitative method by using content analysis that combines tafsìr bi al-ra'yi with tafsīr bi al-ma'thür. By using social tafsir, it is found that Zakat should be an obligatory system and its management must be done centrally by the government. BAZNAS can be a representation of the government to perform the task. Then, it will result in the creation of equal degree and status between mustahiq and muzakki. Meanwhile, the implication of Zakat in the context of social interaction of the society is the creation of tranquility, security, and harmony for the whole society.
\end{abstract}

Keywords: Zakat, Social Tafsìr, Social Psychology

\section{INTRODUCTION}

The command for paying Zakat and praying are mentioned together in Qur'an as much as 22 times. This shows that Zakat is a form of horizontal relationship between humans. Moreover, as a form of worship, it connects vertically to Allah. Zakat is an important principle in Islamic economics with two main functions, i.e. as a form of worship that gives benefit to the giver and ii) as a collective benefit for people in the environment which run the Zakat system (Sakti, 2007).

So far, the study of the collective benefit of Zakat for people who run the Zakat system is always emphasized on the material economic aspects. The tools used for analysis are often modern economic tools. Although it is good, it is necessary to study and analyze the system of Zakat developed in other contexts, especially in the context of social psychology of society. Recalling as mentioned earlier that Zakat is a form of horizontal 
relationship between parties who give the gift of more wealth (muzakki) to the parties who are deficient in property (mustahiq).

Qur'an and hadith as the main source of Islam should become a tool for exploring the significance of distinct Islamic institutions. In other words, one should use the main sources in Islamic scientific khazanah, called the tafsir method. Then, the concept and wisdom which is contained in an ayah in the Qur'an can be explored by the tafsīr method.

Therefore, by using tafsīr method which researchers rarely use, this paper tries to extract the wisdom in the Zakat system and the implications of Zakat on the social psychology of society. In this case, the ayat that becomes the object of research is Surrah al-Tawbah: 103.

This paper used analysis which refers to some books of tafasīr, both of classical and contemporary literature and combines tafsīr bi al-ma'thūr book and tafsìr bi al-dirāyah book. The process of analysis explores some concepts that exist in Sürah alTawbah: 103 and analyze the meaning of lafadh mentioned in that ayah.

Based on the above background, the objectives of research in this paper are to analyze the concept of Zakat as an obligatory system based on Sürah Al-Tawbah: 103; and the implication of Zakat for the social psychology of society based on Sürah Al-Tawbah: 103.

\section{LITERATURE REVIEW}

\section{Zakat and its Position in Islam}

The language of Zakat means البركة والنماء والطهارة والصلاح (blessing, growth, holy, and kindness). Then, the terminology aspect said that Zakat is required by Allah which is some portion of certain wealth to be given to the people who are entitled to receive it (mustahiq). Zakat can increase principal's treasure and keep it from various dangers is the reason why it is called Zakat (Qarḍawī, 1973).

One of the pillars which are foundations of Islam and also has a high position in Islam is Zakat. This is mentioned by Rasulullah:

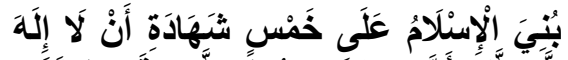

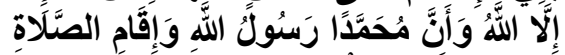

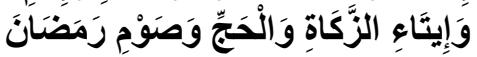

$$
\begin{aligned}
& \text { "Islam is based on (the } \\
& \text { following) five (principles): } \\
& \text { Syahadat Laa ilaaha illa Allah } \\
& \text { and (syahadat) Muhammad } \\
& \text { Rasulullah, to offer the } \\
& \text { (compulsory congregational) } \\
& \text { prayers dutifully and perfectly, } \\
& \text { to pay Zakat, to perform Hajj, } \\
& \text { and to observe fast during the } \\
& \text { month of Ramadhan" (HR. } \\
& \text { Bukhari) }
\end{aligned}
$$

The command for paying Zakat and praying are mentioned together in Quran as much as 22 times shows how important is the position of Zakat in Islam. In addition to that, Zakat is a unique and complete system of redistribution (Rivai, 2013). Zakat regulations in Islam are quite clear. Therefore, the function of Zakat has to become an obligatory system rather than a voluntary system in order to institutionalize it in the lights of Islamic injunctions.

\section{Social Psychology}

Social psychology differs from the other psychological fields which focus solely on individual internal variables as determinants of behavior, such as motivation, needs, and so on (Soeparno, 2011). Social psychology departs from the idea that the recognition of behavior and its process 
takes place in the social sphere (which can affect the individual) and then produce the study of the intra-psychic process in a person in terms of interaction between people (Nurrachman, 2008). Social psychology is the understanding, explanation, and prediction of how the thoughts, feelings, and actions of individuals are influenced by the thoughts, feelings, and actions of others whom they see, or even just imagine (Soeparno, 2011).

\section{Previous Research}

There are several types of research conducted related to the impact of Zakat. First, research conducted by Muhammad Abdullah, Abdul Quddus Suhaib (2011) entitled "The Impact of Zakat on Social life of Muslim Society". The purpose of this study is to explicate the significance of Zakat as an institution, to elaborate the impact of Zakat on social life of Muslim society as it is the basic theme of the study, to cultivate necessary awareness about basic theme among all sections of the society particularly intellectual, elites and opinion leaders and to promote further research about the impact of Zakat on social life of Muslim society so that Zakat as an institution is established in Muslim countries. By using the qualitative methodology, the result shows that the system of Zakat plays an effective and successful role in developing the social life and moral values of Muslim society (Abdullah \& Suhaib, 2011).

Second, research conducted by Eko Suprayitno, Mohamed Aslam, Azhar Harun (2017) entitled "Zakat and SDGs: Impact of Zakat on Human Development in the Five States of Malaysia". The purpose of this research is to examine the impact of Zakat on human development program in Malaysia. The scope of this research is confined to five states in Malaysia, namely, Johor, Kedah, Negeri Sembilan, Selangor, and Terengganu, while the object of research in Human Development. By using the Autoregressive Distributed Lag (ARDL) bound testing approach; the results show that Zakat has a positive and significant influence on human development in five states in the short and long run. Zakat in Malaysia can be used as a tool of fiscal policy that is decided in the states of Malaysia to stimulate human development and economic growth in the long run (Suprayitno, Aslam, Harun, Pan, \& Hotel, 2017).

Resume of previous research is following:

Table 1. Empirical Study

\begin{tabular}{|l|l|l|l|}
\hline No. & Researcher & \multicolumn{1}{|c|}{ Methodology } & \multicolumn{1}{c|}{ Research Result } \\
\hline 1. & $\begin{array}{l}\text { Abdullah, } \\
\text { Abdul } \\
\text { Quddus } \\
\text { Suhaib } \\
(2011)\end{array}$ & Qualitative & $\begin{array}{l}\text { The System of Zakat plays an effective and } \\
\text { successful role in developing the social life } \\
\text { and moral values of Muslim society. }\end{array}$ \\
\hline 2. & $\begin{array}{l}\text { Eko } \\
\text { Suprayitno, } \\
\text { Mohamed } \\
\text { Aslam, } \\
\text { Azhar }\end{array}$ & $\begin{array}{l}\text { Quantitative by } \\
\text { using } \\
\text { Autoregressive } \\
\text { Distributed Lag } \\
\text { (ARDL) bounds }\end{array}$ & $\begin{array}{l}\text { Zakat has a positive and significant } \\
\text { influence on human development in five } \\
\text { states in the short and long run. Zakat in } \\
\text { Malaysia can be used as a tool of fiscal } \\
\text { policy that is decided in the states of }\end{array}$ \\
\hline
\end{tabular}




\begin{tabular}{|l|l|l|}
\hline Harun & testing approach & Malaysia to stimulate human development \\
and
\end{tabular}

\section{METHODOLOGY}

This paper uses content analysis approach, one of the descriptive qualitative methodologies used as a research methodology in qualitative research. According to Berelson (1952) in Stemler (2001), content analysis has interpreted the words based on implicit rules. Meanwhile, according to Holsti (1969) in Stemler (2001), content analysis is specific, objective, systematic technique of interpreting and identifying the message. Content analysis approach that is used by the author is tafsìr method - the way commonly used by Ulama to explore Quran related laws and wisdom which is a combination of tafsir bi alra'yi and tafsìr bi al-ma'thūr.

The definition of Tafsìr bi al$R a^{\prime} y i$ or bi al-Dirāyah is an effort to seek an interpretation of Quran through the thought (ra'yu). Ra'yu means an Ijtihād which brings the balance between logic and basic principles of Ijtihād. People who want do that have to follow the four guidelines (Suyūti, 1998), i.e. i) Do not take the da' $\bar{l} f$ and maudū' hadith when quoting from Rasulullah; ii) Since mufassir judgement related to the opinion of the Prophet's friends is absolute like hadith marfü', hence it should be considered; iii) Mastering Arabic include grammar and iv) examining the arrangement and truly understanding Shari'ah basic rules (al-ușūl alshar'iyyah). Based on that explanation, only certain people are allowed to do so. If the person who has none of these qualifications, then there could be wrong and misleading interpretation. Some of these tafasīr books are Tafsir
al-Jalālain, al-Baidawī, al-Alūs̄̄, alKhäzin and so on.

The definition of Tafsì bi alMa'thūr or bi al-Riwāyah is an effort to seek an interpretation of Quran through the Quran itself, hadith, or the words of the prophet's friends. The tafsir books that belong to this type are Tafsìr al-Țabarī, al-Durr al-Manthūr, Ibn Kathīr, al-Baghawī and many more.

Therefore, the leading tafasìr literary - classical and contemporary tafsir - be explored in this paper for that methodology. Tafsir Ibn Kathīr by Ismā' '̄l bin 'Umar bin Kathīr, Ma'àlim

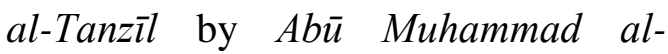
Husain bin Mas'ūd al-Baghāwī, and Mafātīh al-Ghaib by 'Umar bin alHusain al-Rāzi are books of classical tafsìr, while for contemporary tafasīr, author explored are from Tafsir alMunīr by Dr. Wahbah al-Zuhailī and Tafsīr al-Sha'rāwi by Muhammad Mutawallī al-Sha'rāwī.

\section{RESULTS AND DISCUSSION}

The object of this research is interpretation of al-Tawbah: 103, that is

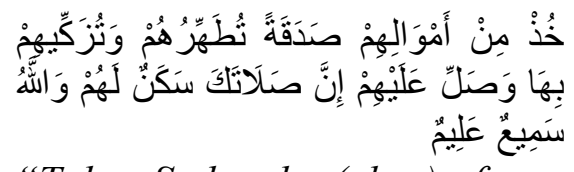

"Take Sadaqah (alms) from their wealth in order to purify them and sanctify them with it, and invoke Allâh for them. Verily! Your invocations are a source of security for them, and Allâh is All-Hearer, AllKnower." (QS. al-Tawbah: 103) 
Based on that ayah, there are two attractive sentences to be discussed. The first one is: خُخْ مِنْ أَمْوَالِهِهْ صَدَقَة

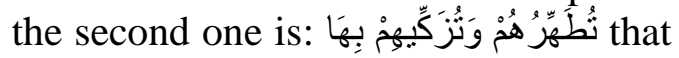
reflects the Zakat function. Both of those sentences have a strong relation. It means that good execution of Zakat concept will lead to the good achievement Zakat function.

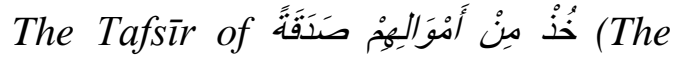
Concept of Zakat as an Obligatory System)

In this part, Allah begins with lafadh خُ (take) which is the command word form (fi'il amr). According to that form, that lafadh is used as a $z \bar{a} h i r$ and we can conclude that the Zakat collection activity is obligatory (Rāzi, n.d.). The opinion before is appropriate to the usul al-figh method. The methodology mentions that the application of the word has to be mandatory as long as no other Dalīl is present which can refuse it.

Rasulullah is the target (mukhätab) of this command word whose duty is to collect Zakat from the group of people with excess wealth (the rich), and Rasulullah carries out the mandate of the implementation (Dimashqi, 1999). Then, the duty becomes the responsibility of the sovereign after him (Zuhailī, 1998). The context of this ayah is at the time when Rasulullah got that duty as a sovereign authority in an Islamic government. Therefore, that duty also becomes the responsibility of the sovereign authority in managing the state afterwards.

In Abū Bakar era, there were people who opposed Zakat and tried to bypass their responsibility of paying Zakat by using the argument that they were no longer responsible to pay
Zakat because Rasulullah had already died. As the sovereign head of the Islamic government, he fought those people and he said:

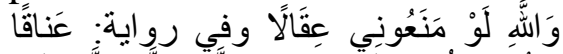

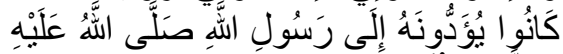

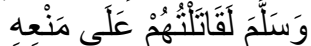

"By Allah! If they refuse to pay even a young goat which they used to pay during the lifetime of Rasulullah, I will fight with them for it." (HR. Bukhāri and Muslim)

In the implementation of Zakat as described above, the government can appoint some officers who handle the collection and distribution of Zakat, known as amil Zakat or 'ämilīn. This is based on the assignment of Mu'adz bin Jabal by Rasulullah - who was the head of state at that time - to take Zakat in the Yaman. In the assignment, Rasulullah gave a message to $\mathrm{Mu}$ 'adz which was presented to the Yamans' residents. The message was as follows:

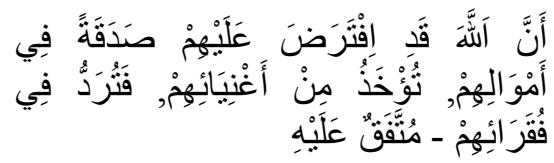

"Indeed Allah has enjoined on them, the Zakat. And it is to be taken from the rich amongst them and given to the poor amongst them" (Muttafaq 'Alaih)

Furthermore, Zakat is the right of the recipient (mustahiq) to be taken from the rich (muzakkî). This statement becomes strengthened by the use of lafadh خُ (taken) in Sürah al-Tawbah: 103 and lafadh تُؤخْذُ (taken) in the above hadith. Thus, Zakat is not a voluntary charity that is left entirely to the consciousness of each individual. Rather, Zakat is obligatory. When muzakkī refuses to give it, then Zakat can be taken by force as was done by 
Abū Bakar. This is based on the confirmation by Allah in Sürah alDhāriyyāt: 19

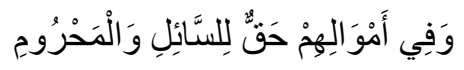

"And in their properties, there was the right of the beggar, and the Mahrûm (the poor who does not ask the others)" (QS. Al-Dhāriyyāt: 19)

Based on that explanation, it can be understood that Islam's view of Zakat is not voluntary, but obligatory. This is a crucial assumption for Zakat function in society's life and economy. The ayah's context explains that Zakat system is obligatory as indicated by

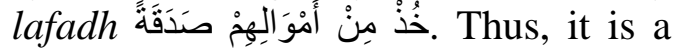
requirement for the functioning of the

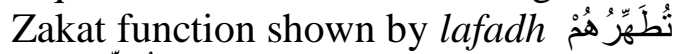
وَتُزَكَِّّهِْْ بِهَا the next discussion.

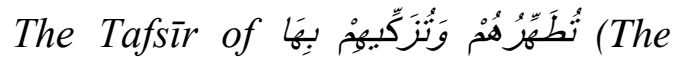
Implication of Zakat for Social Psychology)

In Sürah Al-Tawbah: 103, Allah mentions that the main function of

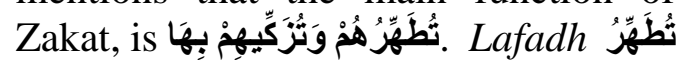
is a fi'il mudāri' from mașdar التطهير. While lafadh التطهير (al-TaŢīr) comes from the syllable طهرة or which

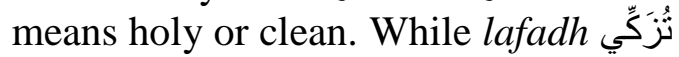
is a fi'il mudâari' from maṣdar التزكية. While lafadh التزكية comes from syllable الزكاة which in language has to mean الطهارة و النَّماء و البَركةُ و الرَدْاة (holy, blooming, blessing, and praise). The use of the word الزكاة for the four meanings is found in the Quran and hadith (Mișrī, n.d.).

Based on the above, التزكية has the same meaning as التطهير. Though, there are several different meanings, the use of lafadz التزكية for meaning

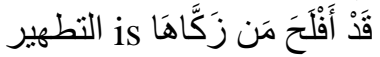

"Indeed He succeeds who purifies his ownself (i.e. obeys and performs All that Allâh ordered, by following the true faith of Islâmic Monotheism and by doing righteous good deeds)." (QS. Al-Shams: 9)

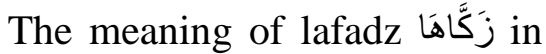
that ayah is طهر ها من الأخلاق الدنيئة و الرذائل (purifying the soul from a low and despicable moral. Even though التزكية has an equation of meaning with التطهير (Dimashqi, 1999). However, according to al-Rāzin, when التزكية called concurrently (affixed) with lafadh التطهير, there must be a difference between the two (Rāzi, n.d.). This is because in the Quran there can be no repetition of the same lafadh without any different meaning or other implied utility.

Based on the above description, there are two meanings given by mufassir for lafadh التزكية in the Sürah al-Tawbah: 103. First, lafadh التزكية has the meaning مبالغة في التطهير وزيادة فيه

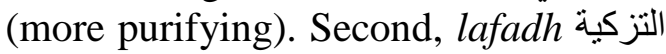
has the meaning الإنماء والبركة في المال (developing and giving blessings to the treasure). It means that Allah will make the loss of property due to Zakat a source for developing, increase, and blessing in the wealth (Zuhailī, 1998).

In this study, we use the first interpretation of مبالغة في التطهير وزيادة فيه (more purifying) in the analysis. It is because this paper is focused on the analysis of Zakat implications on the social psychology of society.

In Arabic grammar, lafadh طهارة can be used for clean or holy

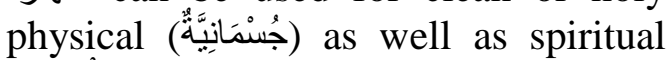
(نَفََْانِيَّة) (Zubaidī, n.d.). The use of lafadh طهارة for spiritual/holy is also often used in the Quran. One of them is 


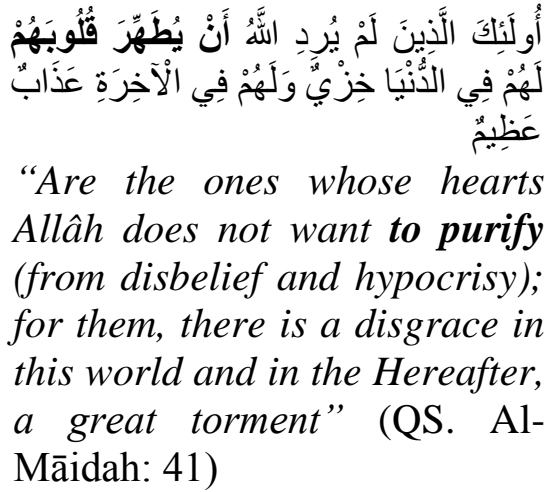

Based on this, we can interpret the function of Zakat in the form of التطهير in Sürah al-Tawbah: 103 as cleansing and purification of the soul. In this case, the function of التزكية which is in the Zakat, according to alSha'rāwī occurs in every element in it, for the recipient (mustahiq), the giver (muzakkī) and the wealth itself (Sha'rāwī, n.d.).

Referring to the opinion of alSha'rāwi, if the function of Zakat is taken as cleansing and purification of the soul, then we can see its implication to mustahiq and muzakki in terms of psychology and the sociology of society. According to this paper, the implications of Zakat in the soul purification of mustahiq and muzakki can be seen from two aspects as follows:

The Implications of Zakat in the Context of Social Equality

There are two important pearls of wisdom proposed by al-Sha'rāwī in the management of Zakat by the government according to (Sha'rāwī, n.d.). First, the avoidance of mustahiq from disgrace for "raising their hand" to ask Zakat from muzakkī. With the management of Zakat by the government, the mustahiq no longer needs to "raise their hand" to ask Zakat because they will directly receive it from the government. Second, it helps in avoidance of negative psychological impacts that occur when Zakat is received directly from muzakkī by mustahiq, especially faqīr and miskin. For example, when the family mustahiq A knows that the muzakki who gave the Zakat is family B, then it will have psychological impacts on family A. For instance, a child from family A will feel inferior when dealing with children from family B because he knows that family $B$ is the one who gave Zakat to his family. It is different when Zakat is managed by the government. Then there will be no poor people who feel contemptible and inferiority when dealing with the rich because they did not know from whom the Zakat they received. The poor know only that as citizens, they get what they deserve from the government which is mandated to ensure the prosperity of all the citizens in the state (Sha'rāwī, n.d.).

The function of Zakat as cleansing and purification of the soul psychologically for muzakki is to eliminate the arrogance and 'ujub (pride themselves) from their hearts. When a muzakki pays Zakat which is obligatory, he will not feel that he is superior with his Zakat payment because Zakat is nothing, but the rights of others who are entrusted to him. When he does not pay Zakat from his wealth, the government has the right to forcibly take it. This is confirmed by Allah in al-Dhariyyā t: 19

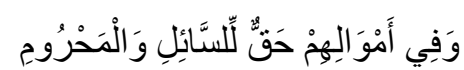

"And in their properties, there was the right of the beggar, and the Mahrûm (the poor who does not ask the others)" (QS. al-Dhariyyāt: 19)

Furthermore, when Zakat is obligatory and is collected and managed by the government, then 
muzakki will not know as to whom the Zakat is distributed. So when looking at the poor, he will not feel meritorious to him. Unlike the case when he directly gives the Zakat to mustahiq, then this will cause negative psychological impact for him by feeling superior to the mustahiq.

Based on this, we can conclude that the implication of Zakat in the context of the equality of society is the creation of equal degree and status between individual mustahiq and muzakkī. Mustahiq psychologically will not feel humiliated and inferior. Similarly, muzakkī psychologically will not feel arrogant, ujub and meritorious to mustahiq.

The Implications of Zakat in the Social Interaction Context of Society

The implication of Zakat in the social interaction context of the society can be seen from the function of Zakat in cleansing the hearts of those who perform it (muzakkī). It positively transforms the greedy and miserly character of a human and makes it more compassionate.. Allah said

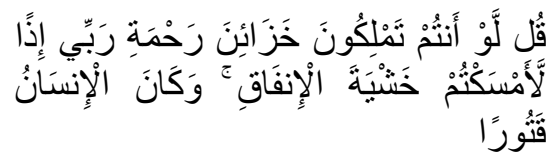

"Say (to the disbelievers): "If You possessed the treasure of the Mercy of My Lord (wealth, money, provision, etc.), Then you would surely hold back (from spending) for fear of (being exhausted), and man is ever miserly!'(QS. Al-Isrā': 100)

In another ayah, Allah also said:

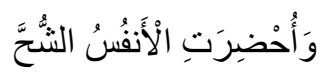

"Even though men's souls are swayed by greed" (QS. AlNisā': 128)
As we have known, wealth is something that is very precious and loved by a human. In fact, sometimes we find someone who loves wealth more than everything including family or even God. Therefore, it is no exaggeration if Rasulullah mentioned

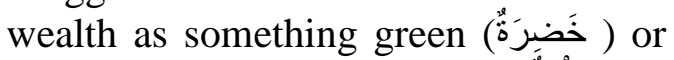
pleasing to the eye and sweet (حُلْوَةُّنَّة ) as recorded by Bukhāri and Muslim.

Excessive love of the wealth often invites greedy virus into the human heart. This greed is described by Rasulullah in a hadith recorded by Bukhāri:

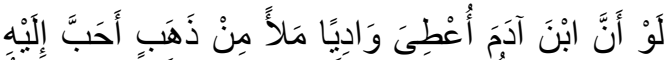

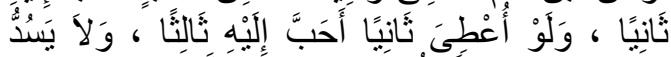

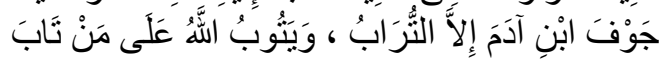
"Had the man been given a valley full of gold, he would have wanted the second again. If he is given the second one, he would want another one. No one can fill his stomach apart from the ground. Allah is receptive to anyone who wants to repent." (HR. Bukhāri no. 6438 )

That greed, in the end, makes people reluctant to give their wealth to others even in the smallest amount. It is more ironic that the waste of little wealth does not bother people as much as giving it to poor people (faqīr or miskīn).

Therefore, it can be appreciated as to why the obligation of Zakat has been established by Allah. Zakat performs an important role to gradually kill the viruses of greed and miserliness in the heart of a human. With the existence of Zakat, the rich are forced to give some of the wealth that Allah entrusts to the person who needs it. Financial obligations of social giving which are charged continuously are expected to make people get used to sharing and caring about the lives of poor people. Therefore, it becomes a 
habit and gradually, the rich not only pay Zakat because as a duty, but will give charity more than the mandatory amount of Zakat. This has been practiced by the Prophet's friends, tābi'ìn, and successors.

Besides cleansing and purifying the heart of muzakkī from the greed, Zakat is also able to purify the heart of mustahiq from envy, anger and jealousy. This envy, anger, and jealousy are often triggered by the high level of inequality. Then, envy, anger and jealousy become the main factor of crimes, such as robbery. In this case, Zakat is one of the instruments to distribute the wealth, which in Islam functions to minimize the inequality. The small inequality leads to reduce the potential for criminalization. Thus, the existence of Zakat is essentially able to keep the wealth of muzakk $\overline{1}$ from the robbery because of the inequality. This is fit with the hadith of Rasulullah

$$
\text { حَصِنُوُ أَمْوَا الَكُمْ بِالزَّكَاةِ }
$$

"Keep your possessions (from

destruction) by (issuing)

Zakat" (HR. Al-Țabrānī)

Awareness of Zakat and the correct and optimal management of Zakat are also capable to give a positive impact to mustahiq. The mustahiq will obtain the benefit from the existence of the rich people whose Zakat payments becomes a source of supplementary incomes for mustahiq. This transforms the attitude and feelings of envy, anger and jealousy to the rich into gratitude and love for them. This is as stated by Rasulullah

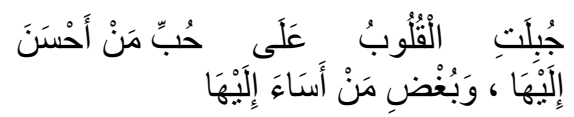

"The attitude of the heart is inclined to love those who do good to him and hate those who do bad to him." (HR. AlBaihaqī in Syu'abul Iman 6: 2985).

In the social context of society, the role of Zakat according to alQardawi is able to provide the strong bond between the rich (muzakkī) with the surrounding community. The bond will always be framed by love and combined with brotherhood and helping each other (Qarḍawī, 1973). In the end, the bond will create a sense of security, peace, and harmony between them. The sense of security, peace, and harmony in this community will become one of the pillars of successful economic development.

Generally, the function of Zakat in social and economic context is explained in Sūrah al-Tawbah: 103. This can be further explained in the following diagram: 


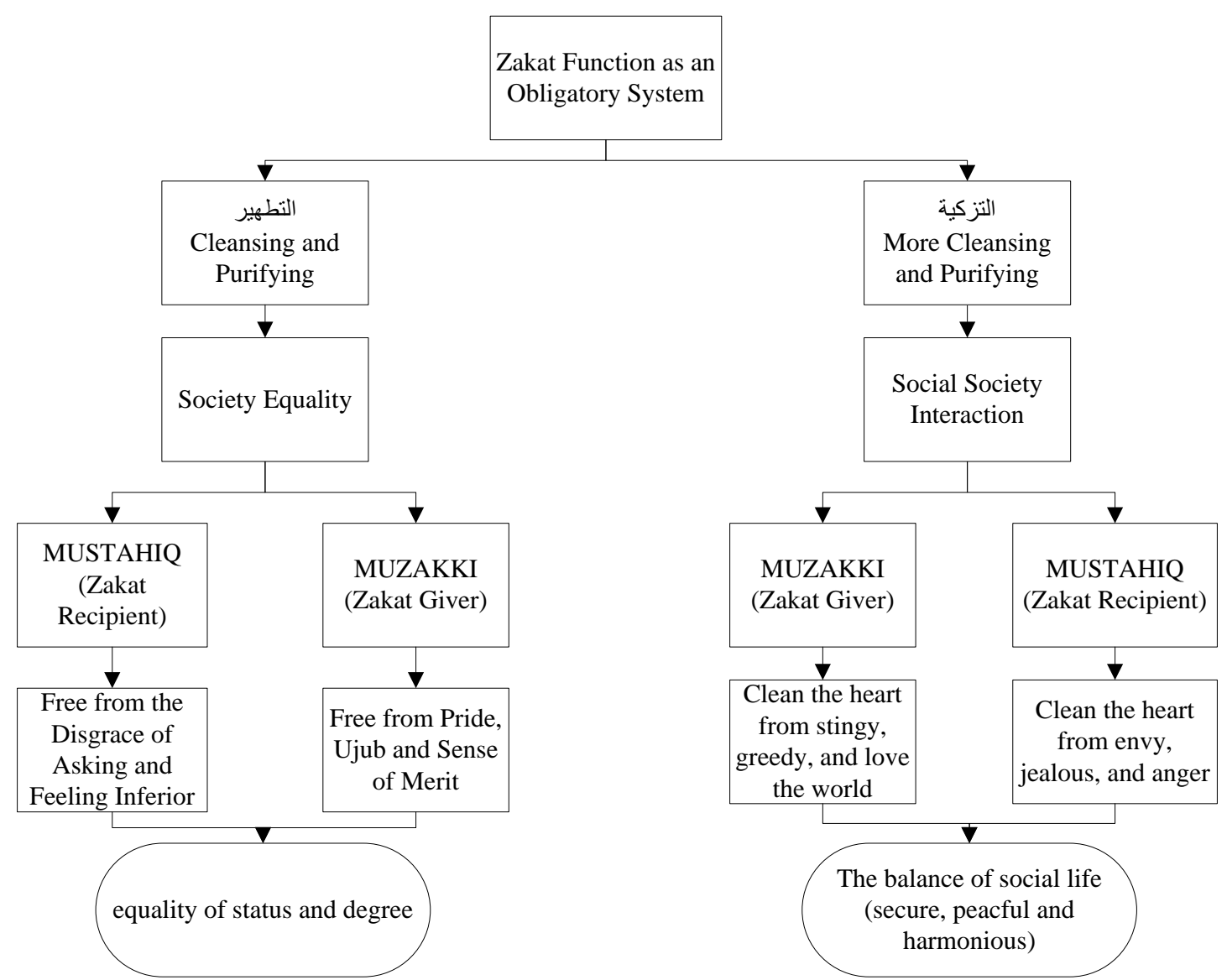

Figure 2. The Zakat Function Diagram in Public Equality and Social Community Interaction Source: Authors' Formulation from Various Sources (2017)

\section{CONCLUSION}

Based on the results and above discussion, it can be concluded that the concept of Zakat based on Sürah AlTawbah: 103 is that Zakat should become an obligatory system, which is managed by the government. Furthermore, Zakat is an obligatory payment to ensure redistribution of resources between mustahiq and muzakki. Similarly, Zakat gives implications in the realization of the balance of life in society with the creation of a sense of security, peace, and harmony in the community

Finally, this research leads to some recommendations. First, Indonesia as a country with the majority of the Muslim population is expected to make Zakat as an obligatory system for the Muslim population. This is because of the huge potential of Zakat which can be collected from the Muslim community of Indonesia, which is the largest Muslim country in the world.

Second, the direct consequence of the implementation of Zakat as an obligatory system is that the management of Zakat is expected to be handled by the government. Government through banking institutions can collect Zakat, and distribute it. In this case, Baznas can be a representative of the government in carrying out the role. Thus, the management of Zakat by the government is able to optimize the function of Zakat for social and economic equality and prosperity. 
Third, the research related to the Islamic economic applications written in the Quran can use the tafsir approach, which is the real and primary treatise in the sources of knowledge in the Islamic epistemology.

\section{REFERENCES}

Abdullah, M., \& Suhaib, A. Q. (2011). The Impact of Zakat on Social Life of Muslim Society. Pakistan Journal of Islamic Research, 8, 85-91.

Dimashqi, I. bin 'Umar bin K. al. (1999). Tafsìr al-Qur'ān al- 'Az̄ìm. Dār Țaybah.

Miṣrī, M. bin M. al. (n.d.). Lisān al'Arab. Bairut: Dār Șādir.

Nurrachman, N. (2008). Integrasi Psikologi: Antara The Knower Dan The Known. Buletin Psikologi, 16(1), 23-28. https://doi.org/10.22146/bpsi.749 3

Qarḍawī, Y. al. (1973). Fiqh al-Zakāh. Bairut: Mu'assasah al-Risālah.

Rāzi, 'Umar bin al-Husain al. (n.d.). Mafātīh al-Ghaib. Bairut: Dār Ihyā' al-Turāth al-'Arabi.

Rivai, V. dan A. B. (2013). Islamic Economics. Jakarta: Bumi Aksara.

Sakti, A. (2007). Ekonomi Islam : Jawaban Atas Kekacauan Ekonomi Modern. Paradigma \& Aqsa Publishing.

Sha'rāwī, M. M. al. (n.d.). Tafsīr alSha'rāwi. Maktabah al-Shāmilah.

Soeparno, K. (2011). Social Psychology: The Passion Of Psychology. Buletin Psikologi, 19(1), 16-28. https://doi.org/10.22146/bpsi.115 44

Stemler, S. (2001). An overview of content analysis. Practical
Assessment, Research \& Evaluation, 7(17). Retrieved from http://pareonline.net/getvn.asp?v= $7 \& n=17$

Suprayitno, E., Aslam, M., Harun, A., Pan, S., \& Hotel, P. (2017). Zakat and SDGs : Impact Zakat on Human Development in the 5 States in. International Journal of Zakat, 2(1), 61-69.

Suyūṭi, J. al. (1998). al-Itqān fi "Ulūm al-Qur"ān. Bairut: al-Maktabah al-"Așriyyah.

Zubaidī, A. al-F. M. al. (n.d.). Tāj al'Arūs min Jawāhir al-Qāmūs. Mauqi' al-Warrāq.

Zuhailī, W. bin M. al. (1998). Tafsìr al-Munīr fì al- "Aqīdah wa alSharī"ah wa al-Manhaj. Bairut: Dār al-Fikr.

Abdul Wahid Al-Faizin

Airlangga University alfaiz165@gmail.com

Taqiyah Dinda Insani Airlangga University tdindainsani@yahoo.com

Tika Widiastuti Airlangga University tika.widiastuti@feb.unair.ac.id 